\title{
Nitrogen fertilizer use in California: Assessing the data, trends and a way forward
}

by Todd S. Rosenstock, Daniel Liptzin, Johan Six and Thomas P. Tomich

Nitrogen fertilizer is an indispensable input to modern agriculture, but it also has been linked to environmental degradation and human health concerns. Recognition of these trade-offs has spurred debate over its use. However, data limitations and misinformation often constrain discussion, cooperative action and the development of solutions. To help inform the dialogue, we (1) evaluate existing data on nitrogen use, (2) estimate typical nitrogen fertilization rates for common crops, (3) analyze historical trends in nitrogen use, (4) compare typical nitrogen use to research-established guidelines and (5) identify cropping systems that have significant influence on the state's nitrogen cycle. We conclude that a comprehensive grower self-monitoring system for nitrogen applications is required to improve nitrogen-use information and to better support evidence-based decision making. The discussion here presents a primer on the debate over nitrogen fertilizer use in California agriculture.

$\mathrm{N}$ itrogen fertilizer is an essential resource for agriculture, and its use has undoubtedly benefited California and its citizens. However, overuse of nitrogen fertilizer threatens the health of the state's agricultural, human and natural resources. On the one hand, nitrogen is necessary for crop growth and development, and thus nitrogen fertilizer use supports California's robust agricultural economy and rural society. On the other hand, applying nitrogen in excess has been linked to water and air pollution, depletion of the ozone layer, climate change and numerous human health concerns (Galloway et

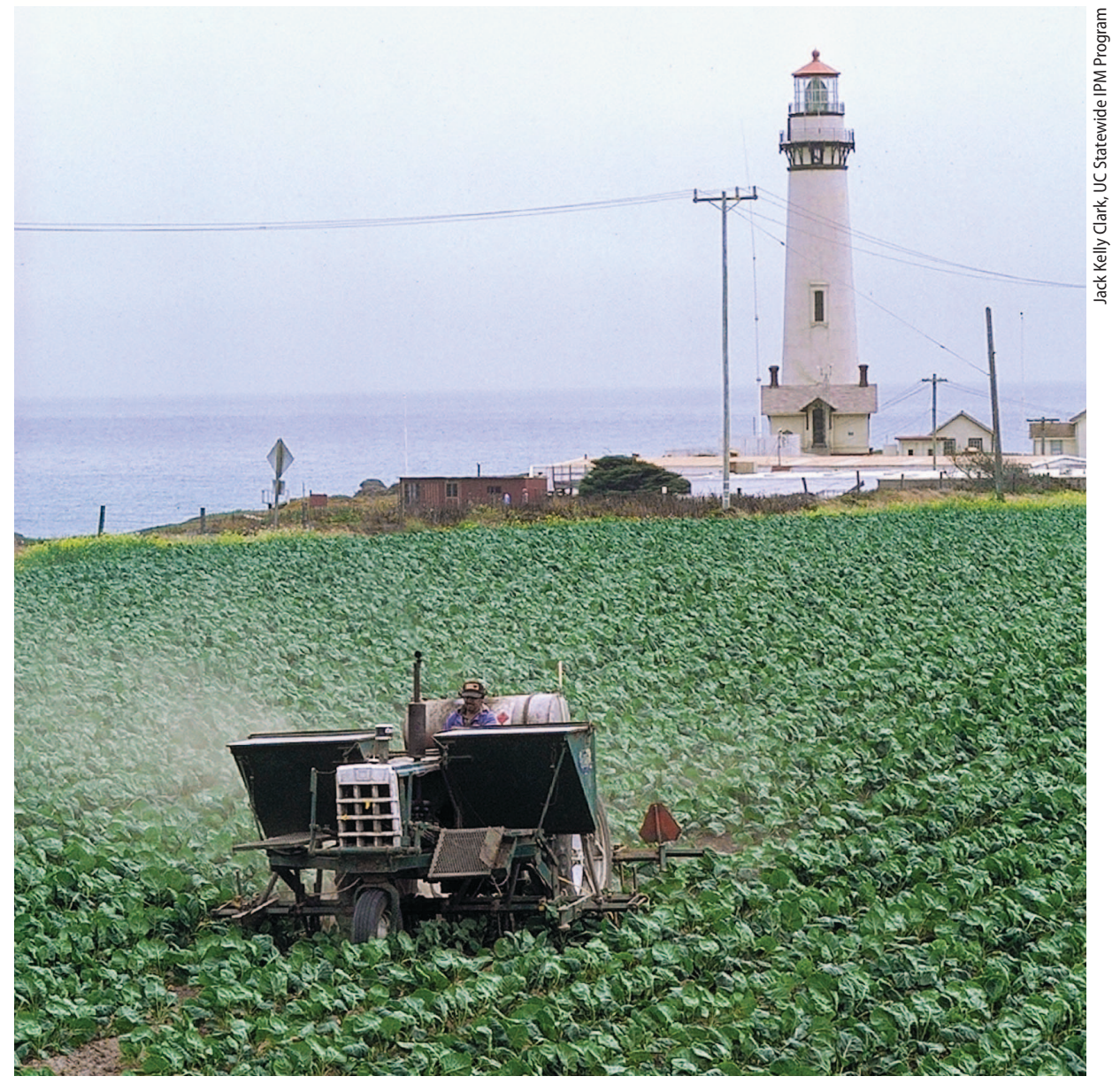

Tractor operator applies fertilizer to cole crop plants near Pigeon Point Lighthouse, San Mateo County. Nitrogen fertilizer is an essential resource for agriculture, but its overuse can threaten human health and the environment.

al. 2003; Millennium Ecosystem Assessment 2005).

The trade-offs that nitrogen fertilizer use present to society have been documented in California for more than 50 years (Harding et al. 1963; Proebsting 1948). It is worth noting that fertilizer is just one way humans add reactive nitrogen into the environment, and other activities such as fossil fuel combustion and waste discharge contribute to the aforementioned concerns. However, a forthcoming report indicates that inorganic nitrogen fertilizer use is responsible for the largest fraction, by far, of new nitrogen introduced into California's environment each year (Liptzin and Dahlgren, unpublished data).

The amount of inorganic (chemical) nitrogen fertilizer sold in California has risen dramatically over the past 70 years (fig. 1). By the 1970s, nitrogen fertilizer sales - and presumably use - exceeded 400,000 tons of nitrogen contained in inorganic fertilizer per year, and in the subsequent decade sales grew more than $25 \%$ to more than 500,000 tons of nitrogen per year. Between 1980 and 2001, the average amount of nitrogen sold per year was no longer increasing significantly, but annual sales have surpassed 600,000 tons of nitrogen in some years. Large upward trends in fertilizer sales in the last half of the twentieth century are not

Online: http://californiaagriculture.ucanr.edu/ landingpage.cfm?article=ca.E.v067n01p68\&fulltext=yes DOI: 10.3733/ca.E.v067n01p68 
unique to California; similar increases are evident throughout the developed world (Millennium Ecosystem Assessment 2005). As nitrogen fertilizer use has expanded, so has the evidence documenting the negative consequences of reactive nitrogen on human health and the environment (Davidson et al. 2012; Townsend et al. 2003).

Today, nitrogen in general and nitrogen fertilizer use specifically both figure prominently in regulatory discourse. Federal and state agencies tasked with protecting air and water quality as well as with mitigating climate change are evaluating the causes, consequences and costs of agricultural nitrogen use. Examples of this concern in California include the UC Center for Watershed Sciences' report to the California Legislature on nitrate in drinking water, the Central Coast Regional Water Quality Control Board's (RWQCB) renewal process for the Irrigated Agricultural Lands Waiver, the Climate Action Reserve's nitrogen fertilizer reduction protocol, the Central Valley RWQCB's Irrigated Lands Regulatory Program, the Central Valley SALTS program and the Central Valley RWQCB's General Order for Dairy Waste Dischargers. The latter, for instance, regulates nitrogen fertilizer application on croplands associated with dairies, constraining its use.
It is important that credible and comprehensive scientific information on nitrogen use be available to support evidence-based policy-making. Without information based on sound science, nitrogen policies may be poorly prescribed, ineffective, cause unintended consequences or even be counterproductive. Stakeholders recognize this and have identified the need for more information

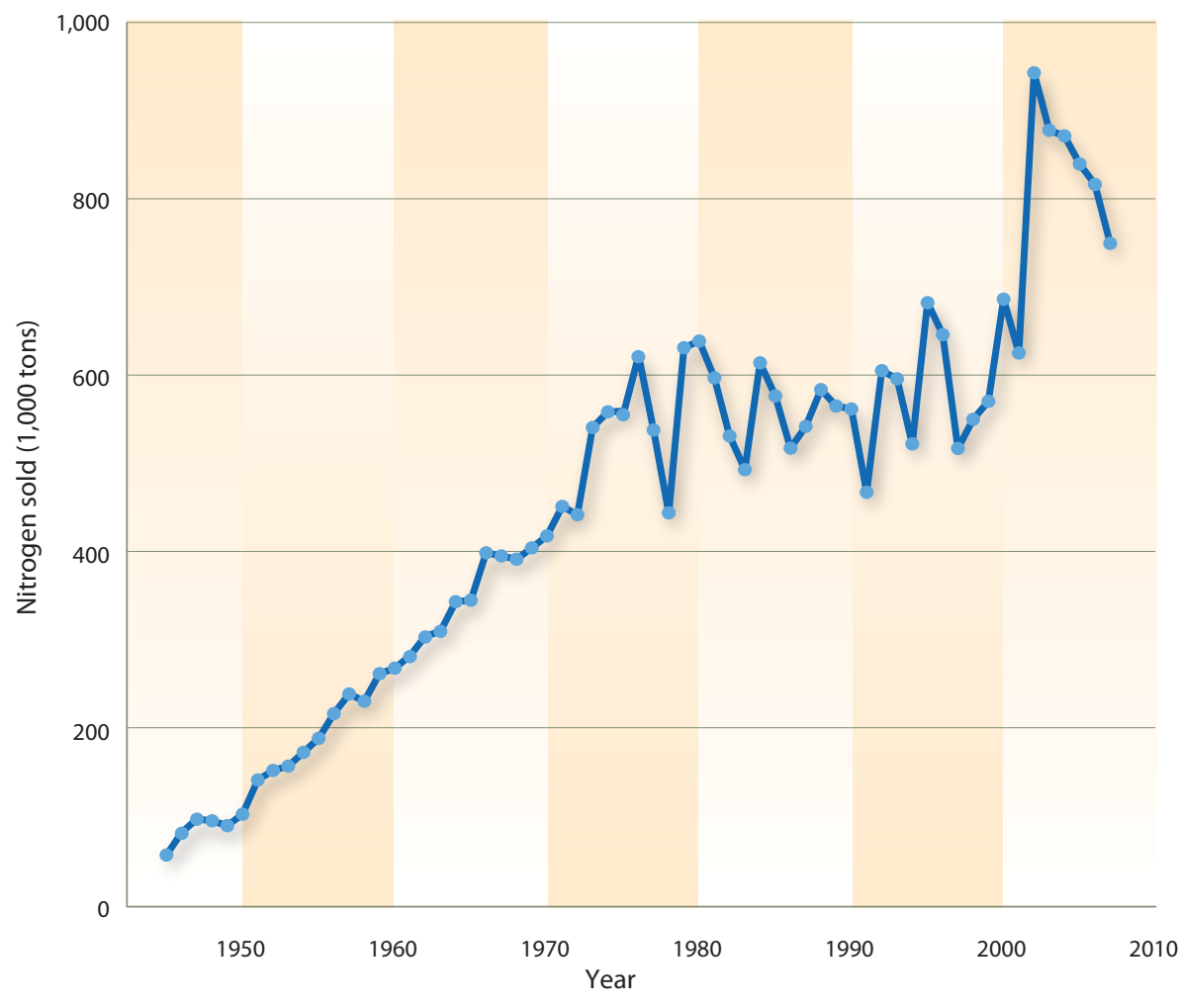

Fig. 1. Statewide sales of nitrogen fertilizer, 1945-2008. Because there is no explanation for the $50 \%$ rise in sales from 2001 to 2002, the largest 1-year change since estimates began, there is reason to question the accuracy of data since 2001. Source: California Department of Food and Agriculture.

\section{Background and scope of this article}

This article reports research from one part of the California Nitrogen Assessment (see sidebar page 70). Assessments are an increasingly common method scientists use to analyze existing data sets and gain a big-picture view of what is known and what is scientifically uncertain

The best example of an assessment is the global effort that led to reports by the Intergovernmental Panel on Climate Change (Ash et al. 2010; IPCC 2007; MA 2005). Recently, the Integrated Nitrogen Committee published an assessment of nitrogen in the United States (Integrated Nitrogen Committee 2011).

Here the authors assess existing knowledge on inorganic nitrogen fertilizer flows, practice and policy in California agriculture - knowledge that has only now been integrated and analyzed as a whole. They examine how statistics are generated, identify sources of uncertainty and compare and interpret data.

Scope. The research scope is limited to inorganic nitrogen fertilizer. Dairy manure, for instance, is not considered, although it is a high priority for attention by scientists and policymakers - and is included in the larger California Nitrogen Assessment (http://nitrogen.ucdavis. edu). Dairy manure application adds about 200,000 tons of nitrogen to California soil per year, an amount equivalent to more than onethird of the annual inorganic nitrogen sold in recent years, and it is applied to a relatively small number of forage crops.

Limits. The authors examine soil nitrogen cycling processes, which include exchanges of nitrogen between the soil and either air or water. However, the discussion is intentionally general; it does not capture nitrogen transformation or emissions under various soil, crop and water management conditions. Further analysis and experiments are needed to draw conclusions regarding the fate of nitrogen in specific fertilized and irrigated systems.

Stakeholder questions addressed. This article addresses stakeholder questions about nitrogen management practices in cropping systems. It presents the best available information that applies to these questions: How is nitrogen fertilizer currently being used? What are the current nitrogen rate recommendations? Are those recommendations adequate for present-day cropping conditions?

More information on the stakeholder process can be found at http://nitrogen.ucdavis.edu. - Editor 
on inorganic nitrogen fertilizer use as a high priority task (http://nitrogen.ucdavis.edu).

Accurate data on nitrogen fertilizer use are difficult to come by, however. Either nitrogen fertilizer use is simply not tracked at relevant scales, as is most often the case, or the data sources are inconsistent (see discussion of grower and expert surveys below). Despite the policies are developed in the future. The objective of this research is to assess the available information on nitrogen use in California by (1) identifying data sources and their limitations, (2) establishing average nitrogen application rates by crop, (3) determining historical trends in nitrogen use (within the context of changes in crop yield) and (4) comparing how average nitrogen application rates articulate

\section{Without information based on sound science, nitrogen policies may be poorly prescribed, ineffective, cause unintended consequences or even be counterproductive.}

fact that this data scarcity makes current estimates of nitrogen fertilizer use uncertain, the estimates still serve as an input to policy discussions. For example, the Intergovernmental Panel on Climate Change (IPCC) suggests that estimated application of nitrogen fertilizer to cropland is a key parameter to use in approximating cropland emissions of nitrous oxide, a potent greenhouse gas.

Because of the relationships among fertilizer use, crop yields, resource degradation and the current policy environment in California, information on nitrogen use is in high demand now and will become of even greater importance as with nitrogen rate guidelines. We go on to show that these results identify crops that have significant influence on nitrogen use, and we suggest this information can then be used to set priorities for research, outreach or policy. This evaluation of the current state of knowledge on nitrogen fertilizer use is part of a broader assessment of nitrogen in California, the California Nitrogen Assessment (see box below).

Scientific assessments, such as the California Nitrogen Assessment, have become a common method scientists use to inform policymakers on complex social and environmental issues. Instead of generating new research, these assessments analyze existing bodies of research, data and models. Assessments generate insights through the synthesis and integration of available information from multiple scientific disciplines to distinguish that which is known and well established from that which is unknown and scientifically uncertain. Assessments piece together the best available information to inform discussions, systematically calling out uncertainty. The assessment of nitrogen fertilizer use reported here relied on standard assessment methods, such as engaging stakeholders to frame the scientific question, aggregating available information and identifying sources of uncertainty (Ash et al. 2010).

\section{The nitrogen cycle}

There are no easy solutions to managing the trade-offs associated with agricultural nitrogen; this is due to (1) the complexity of the nitrogen cycle in general (fig. 2) and (2) the mobility and diversity of soil nitrogen compounds in particular. The vast majority of nitrogen in soils is in soil organic matter and hence does not pose an immediate threat to the environment or humans. This soil organic matter serves as a nitrogen reservoir, and each year a fraction of this nitrogen is mineralized to ammonium. Soil microbes can then turn ammonium into nitrate via

\section{What is the California Nitrogen Assessment?}

The California Nitrogen Assessment (CNA) is a comprehensive effort to examine existing knowledge on nitrogen science, policy and practice in California. Researchers have collected and synthesized a large body of data to analyze patterns and trends in nitrogen inputs, outputs and storage throughout the state. The aim is to more effectively link science with action, and inform policy and field-level practice.

The CNA includes:

- Identification of underlying drivers (e.g., regulations, population growth) and direct drivers (e.g., fertilizer use, soil management and fuel combustion) that affect stocks and flows of nitrogen in California agriculture.

- Calculation of a mass balance to examine how nitrogen moves through California agroecosystems and the state as a whole (including agriculture, sewage, industry and transportation).

- Evaluation of the state of knowledge about nitrogen's impacts on ecosystem health and human well-being.

- A suite of practices and policy options and the potential effects each would have on agriculture, the environment and human health.
- Communications to help the public understand the nitrogen cycle and to help decision makers at the farm and public policy levels.

The CNA is a project of the Agricultural Sustainability Institute at UC Davis and the UC Sustainable Agriculture Research and Education Program.

For more information:

General information on California Nitrogen Assessment (CNA) http://nitrogen.ucdavis.edu

Basics of nitrogen biogeochemistry and the CNA's mass balance http://nitrogen.ucdavis.edu/research/nitrogen/n-science/n-biogeochemistry Information on stakeholder involvement, review and questions http://nitrogen.ucdavis.edu/research/nitrogen/n-stakeholders/ nitrogen-stakeholders

Major funding for the California Nitrogen Assessment is provided by a grant from the David and Lucile Packard Foundation. Work on the assessment began in January 2009 and will continue through 2013. Institutional partners are the UC Agricultural Issues Center and the Kearney Foundation of Soil Science. — Editors 


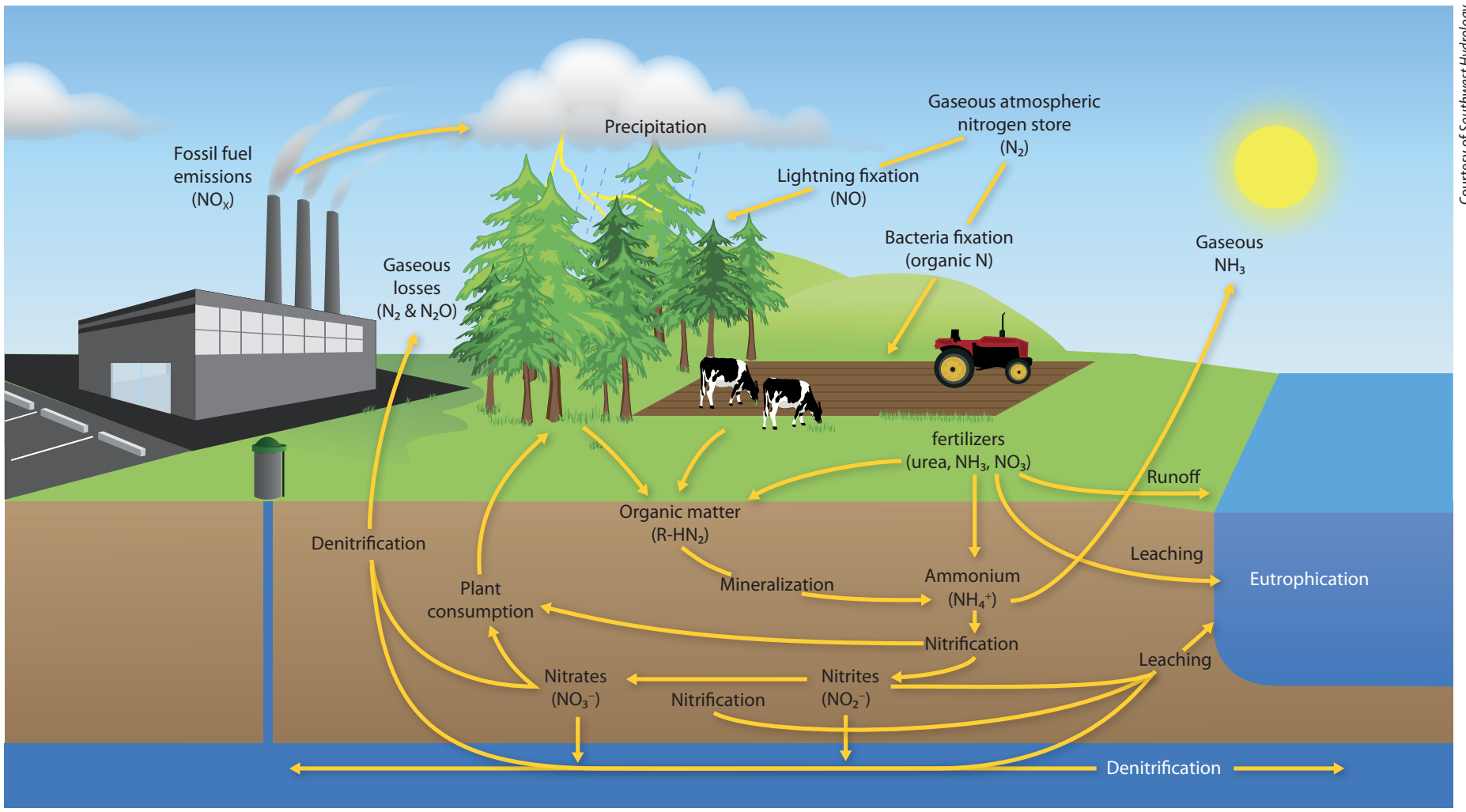

Fig. 2. The nitrogen cycle. Nitrogen in the environment is mobile and readily transformed into various compounds by physical, chemical and biological processes. Arrows indicate major nitrogen-cycling processes, which continuously produce diverse nitrogen compounds in the environment.

\section{Glossary: Nitrogen in soils}

Nitrogen may enter the soil from the atmosphere through rainfall, lightning, and nitrogen fixation by soil organisms; through plant and animal decomposition, or through applied manures and commercial fertilizers. It may be lost by plant removal, volatilization, leaching or erosion. It transforms continuously in soil, air and water.

Ammonification (mineralization): During decomposition of plant or animal material, specialized soil bacteria transform nitrogen to ammonia $\left(\mathrm{NH}_{3}\right)$ or ammonium $\left(\mathrm{NH}_{4}{ }^{+}\right)$; the latter is useful to plants.

Ammonium $\left(\mathrm{NH}_{4}{ }^{+}\right)$: This form of nitrogen can be used by plants, or converted to nitrate by bacteria (and then taken up by plants). It is a positively charged ion (cation), attracted to negatively charged soil clay. For this reason, it is not leached to a great extent.

Denitrification: In this anaerobic process, other specialized bacteria change nitrate back to nitrogen gas, reducing pollution of groundwater but increasing nitrogen oxides in the air. Denitrification occurs only when oxygen is low, such as during flooding and in clay soils. Because most California soils are coarse and weldrained, denitrification occurs less often, and soils are more vulnerable to nitrate contamination of water supplies by leaching.

Nitrification, nitrite $\left(\mathrm{NO}_{2}{ }^{-}\right)$and nitrate $\left(\mathrm{NO}_{3}{ }^{-}\right)$: Specialized bacteria change ammonia to nitrite, and still others change nitrite to nitrate. Both processes are nitrification, and they are aerobic, occuring only when oxygen is present. Nitrate is the principal form of nitrogen used by plants. Because it is negatively charged (an anion) and is not attracted to soil clay, it leaches easily and is a water pollutant. Nitrate-enriched groundwater can also contribute to algal blooms in streams, although most such blooms result from nitrogen- and phosphorus-enriched surface runoff.

Nitrogen gas $\left(\mathbf{N}_{2}\right)$ : Dinitrogen gas occurs when two nitrogen atoms form a very strong trivalent chemical bond; it comprises 78\% of the atmosphere. Although largely inert, nitrogen gas can be "fixed" into biologically useful forms in the soil (see first paragraph).

Nitrogen loss (leaching, erosion): Nitrogen losses from the soil system occur by plant removal, denitrification, leaching, volatilization and erosion. Plant removal by crops is fertilization. Erosion and leaching can contribute to ground and surface water pollution.

\section{Nitrogen, organic (nitrogen in living or once-living things):} "Organic nitrogen" originated in living material and is still part of a carbon-chain complex. It can enter soil as decomposed plant or animal tissue. It is not available to plants until microorganisms transform it to ammonium $\left(\mathrm{NH}_{4}{ }^{+}\right)$.

Nitrogen, reactive: Reactive nitrogen is all nitrogen other than dinitrogen gas $\left(\mathrm{N}_{2}\right)$.

Volatilization: Soil microorganisms convert ammonium nitrogen to ammonia gas in soils with a high $\mathrm{pH}$, that is a $\mathrm{pH}$ greater than 7.5. Such soils are not common in California.

Glossary sources include an article by Thomas Harter in the July/August 2009 Southwest Hydrology. - Janet White 
the process of nitrification. Both forms of nitrogen, ammonium and nitrate, are available for plant uptake. Mineralization supplies as much as half or more of the nitrogen to crops (Gardner and Drinkwater 2009). The reverse process (immobilization) entails the integration of the inorganic nitrogen produced by mineralization into the living biomass of plants and microbes.

Nitrogen compounds can also be released from the crop root zone through multiple processes. Leaching relates to the physical movement of nitrate downward through the soil profile. Volatilization is a physiochemical process that emits gaseous ammonia. Denitrification is a microbial-mediated release of inert dinitrogen gas and potentially nitrogen oxides including nitrous oxide. It is the emission of these nitrogen compounds that threatens the health of California's environment and human population.

The rate at which nitrogen cycling occurs in soils is a function of a multitude of abiotic (precipitation and temperature), biotic (microbial communities) and humanmediated (such as tillage and nitrogen fertilizer application rate) factors.

\section{Fertilizer and excess nitrogen}

Adding inorganic nitrogen fertilizer to soil promotes high plant productivity and

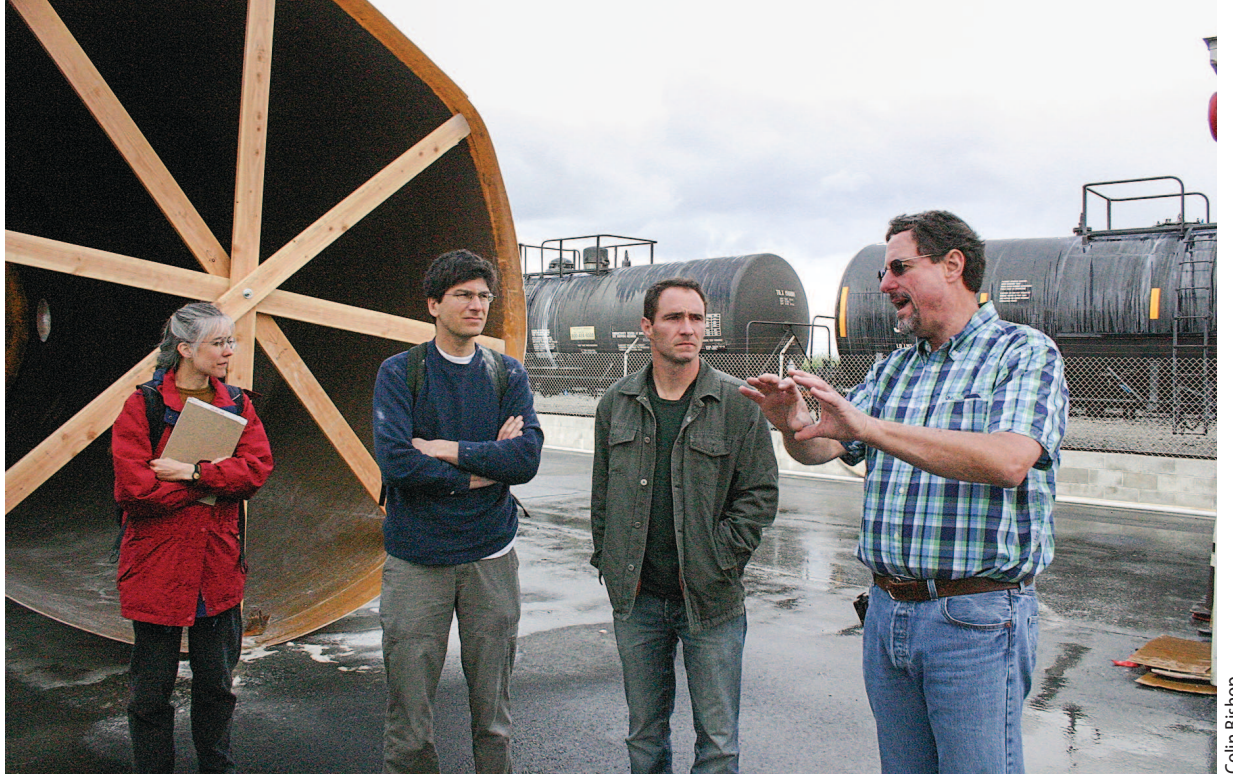

Sonja Brodt, Daniel Liptzin and Todd Rosenstock learn about fertilizer production from Ken Johnson of TSI Fertilizer Manufacturing in Dixon. Large upward trends in fertilizer sales in the last half of the twentieth century are evident throughout the developed world.

long-term soil fertility (Ladha et al. 2011), but this can also cause large surpluses of nitrogen in the environment. This excess nitrogen can lead to environmental degradation by percolation (leaching) through the root zone and into groundwater, through surface runoff into waterways, or via emissions of nitrogen gases such as ammonia, nitric oxide or nitrous oxide into the atmosphere. Gaseous and waterborne nitrogen may be related to nitrogen fertilizer application rates in linear and nonlinear ways, which means application rates alone are not always enough to determine how much is lost to the

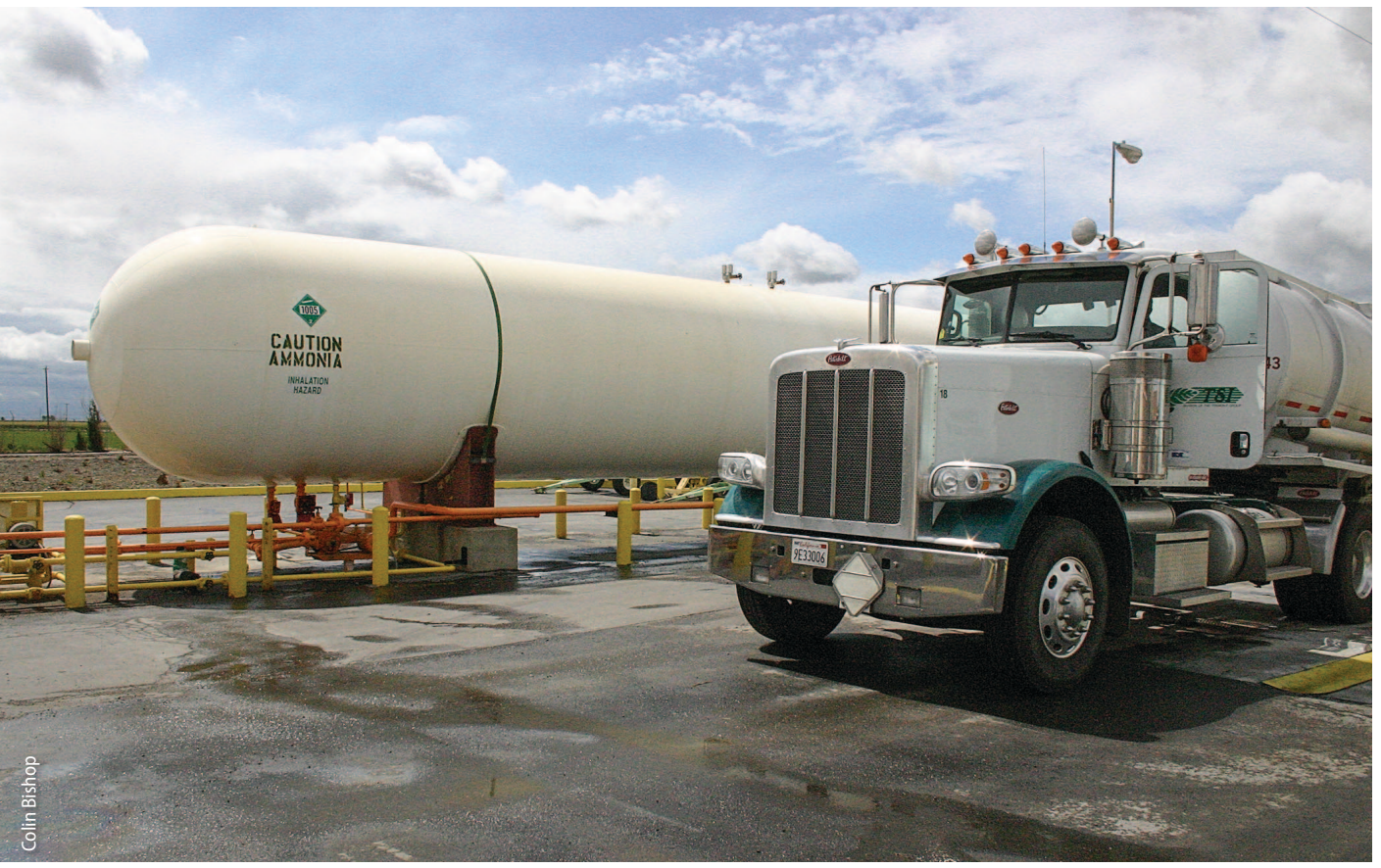

Fertilizer trucks transport liquid ammonia throughout the state. Adding inorganic nitrogen fertilizer to soil promotes high plant productivity and long-term soil fertility but can also lead to excess nitrogen in the environment and environmental degradation. environment (Broadbent and Rauschkolb 1977; Hoben et al. 2011; Linquist et al.

2012). Recent evidence suggests that the best indicator of potential nitrogen loss into the environment is the "surplus" nitrogen, which is the difference between the nitrogen applied as fertilizer and the nitrogen taken up by the crop (Van Groenigen et al. 2010). Therefore, both nitrogen application rate and nitrogen surplus, which is calculated after the crops are harvested, are important factors for predicting where nitrogen loss should be highest.

\section{Nitrogen-fertilizer-use data}

Data on nitrogen fertilizer use in California are scarce and fragmented. Typically, data are less available and more variable at finer spatial resolutions. The following identifies the primary sources of data available for statewide and county nitrogen use and nitrogen application rates by crop, and discusses some of the inherent limitations of these data sources.

\section{Statewide nitrogen fertilizer use.}

Fertilizer sales data are collected by the California Department of Food and Agriculture (CDFA) and reported the state and county levels. Since fertilizer sales are only recorded when a licensed fertilizer dealer sells to an unlicensed buyer, these data provide a rough approximation of the total inorganic nitrogen applied statewide, assuming no stockpiling or interstate transfer of fertilizing materials (fig. 1). Annual data are available dating back to 1945 . However, there are additional reasons to question the accuracy of these data. Perhaps the most obvious is the unexplainable $50 \%$ jump 
in sales between 2001 and 2002, the largest 1-year change since annual estimates began. And the reported sales remained abnormally high in the following 5 years (2003 to 2007). Because there is no explanation for this large jump in reported fertilizer sales statewide - neither its root cause nor an apparent accounting error - we have little confidence in the data reported since 2001.

County nitrogen fertilizer use. While fertilizer sales data are reported to CDFA at the county level, the precision of these data is problematic. County fertilizer data portray a geographic distribution of sales unlikely to match actual use for most counties. This is due to the method of data collection, which neglects fertilizer transported from one county to another. For example, more than $20 \%$ of total statewide nitrogen sales were reported to have taken place in San Joaquin County. It is entirely possible that this value can be attributed to the large quantity of ammonia delivered to the Port of Stockton and redistributed from there. County-level sales data may be an appropriate proxy for nitrogen applications in counties where one does not suspect significant transport of nitrogen into or out of the county, but it is not possible to be certain with the current data collection system.

Nitrogen fertilizer use by crop. There is neither a comprehensive source of information nor current estimates of average nitrogen applications by crop in California. The most complete source of data in California is a 1973 survey of approximately 120 UC experts and affiliates about nitrogen application rates on 45 commodities (Rauschkolb and Mikkelsen 1978). (The term "expert" in this article refers to UC employees - faculty, farm advisors and facility managers - but we acknowledge there are many other sources of expertise.) However, these rates are unlikely to be the same today due to changes in irrigation technology, tillage, cultivars and countless other management practices since the 1970s. While a few other expert estimates are available, they generally cover fewer crops than the 1973 survey (Miller and Smith 1976; Zhang et al. 2009).

Data direct from growers are largely unavailable. In a few instances, surveys have been conducted (Hartley and van Kessel 2003), though they sometimes omit asking for (Lopus et al. 2010) or reporting

(Dillon et al. 1999) nitrogen application rates. The only systematic source of nitrogen application data based on grower surveys is the USDA Agricultural Chemical Use Program reports (USDA NASS 2010). The USDA surveys growers for nitrogen fertilizer application rates for major crops on a rotating schedule, with an emphasis on field crops. As a result, surveys on nutrient use for each crop only occur intermittently — sometimes with significant time elapsing between information being gathered for certain crops. For example, almond was surveyed in 1999 and 2009. Though long-term trends may be detectable from such data, there is the distinct possibility that they may be obscured by year-to-year variability in data that is not quantified and therefore cannot be taken into account. Furthermore, some

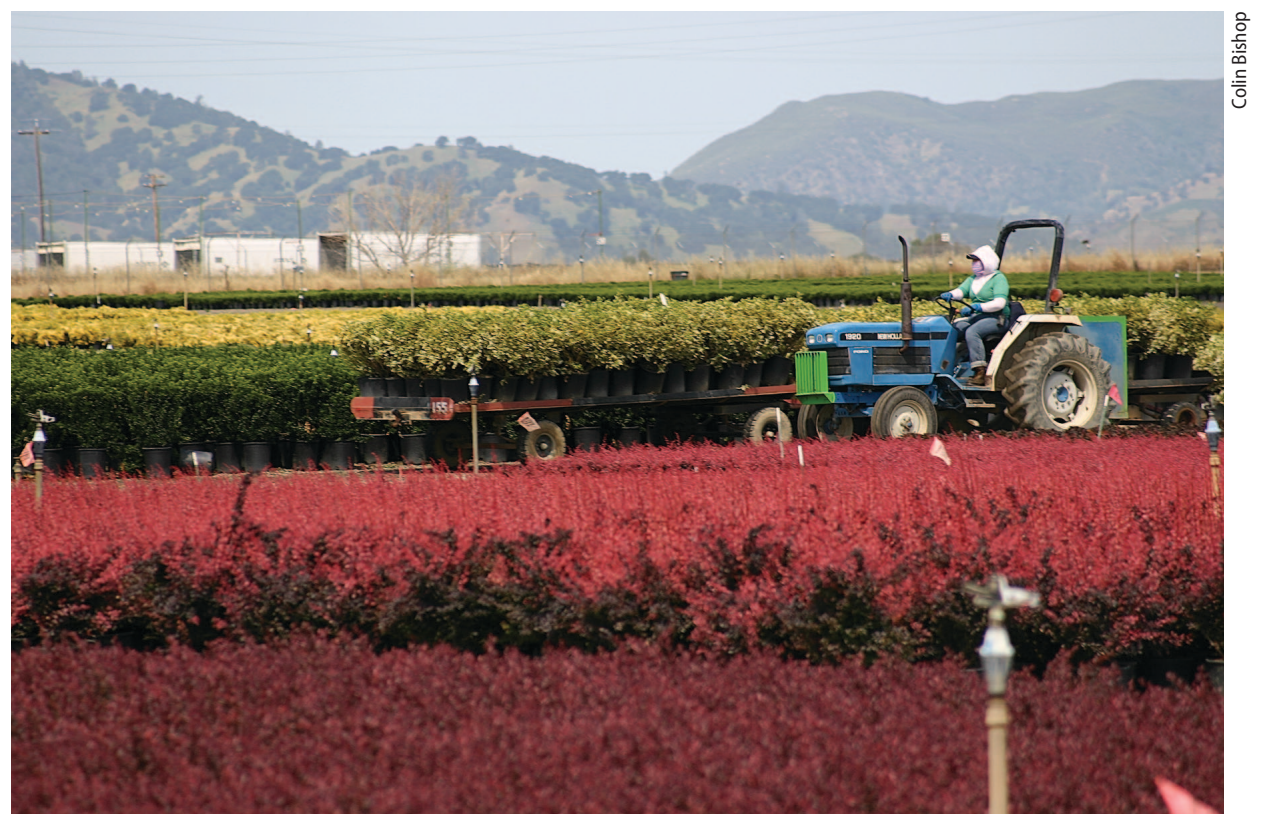

A farmworker applies fertilizer to nursery crops in Winters in the Central Valley. At present, there is neither a comprehensive source of information nor current estimates of average nitrogen applications by crop in California.

crops that contribute significantly to California's agricultural economy are not customarily surveyed in any state (such as fresh-market tomatoes), not surveyed in California (such as corn) or not surveyed for nutrient use (such as nursery and greenhouse plants).

\section{Assessing crop nitrogen use}

Developing new estimates of nitrogen use by crop is critical to informing the research, outreach and policy agenda on nitrogen fertilizer use. Surveys are resource intensive, and their design and scale may make it difficult to achieve a representative sample, especially in the diverse California agricultural landscape. In addition, the California Nitrogen Assessment had little success in an effort to survey UCCE employees about nitrogen use, and commodity boards about nitrogen research; the response rate was less than $7 \%$ and less than $15 \%$, respectively. In place of a new survey, we developed and utilized a new approach to estimate an average nitrogen application rate by crop based on available data. The premise underlying this assessment was to smooth out some of the uncertainties and variation in these data by aggregating across sources. We compiled the available information from expert and grower sources into a database according to the methods described below. 


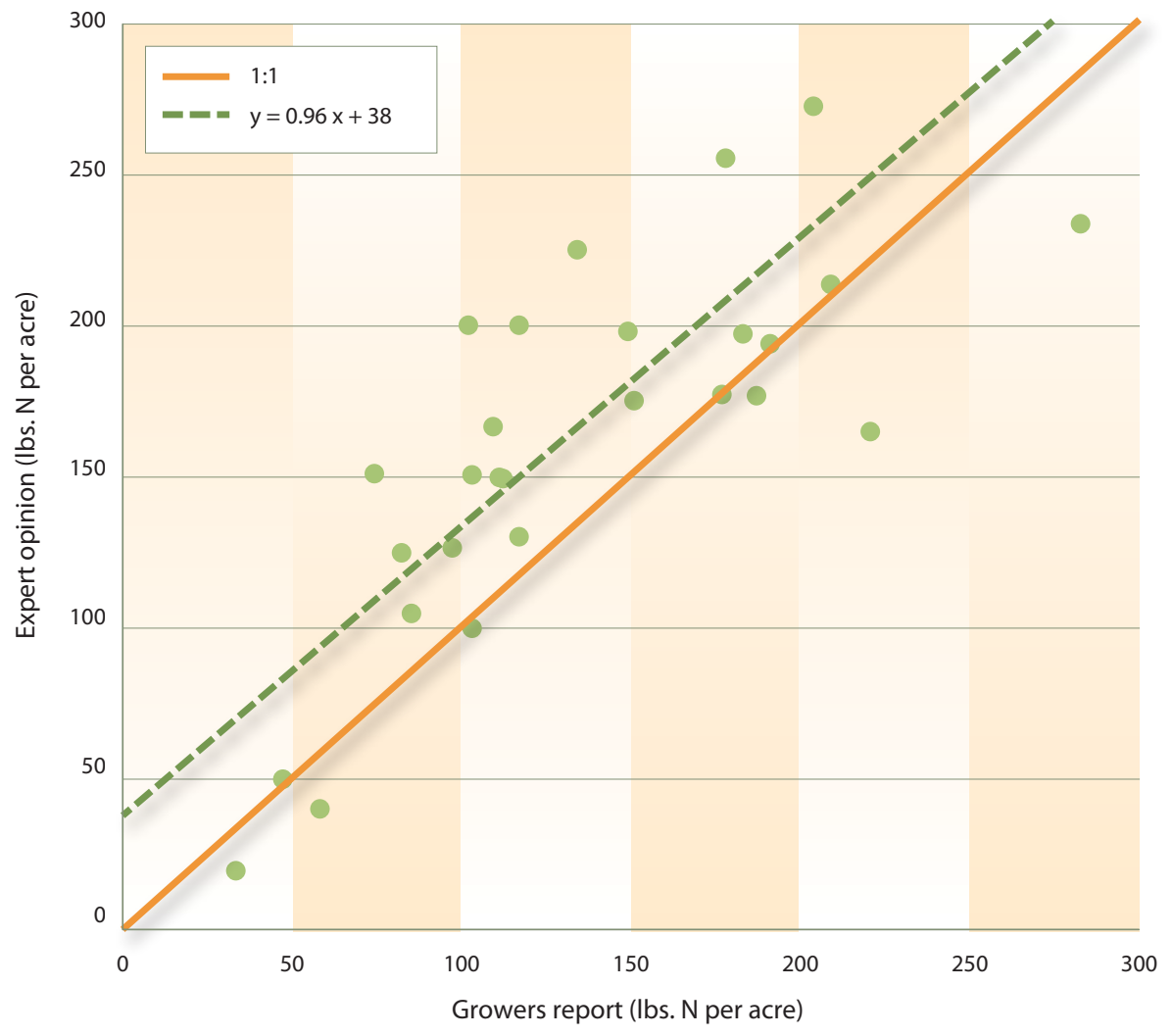

Fig. 3. Relationship between the experts' opinions and growers' reports of nitrogen application rates. Data were available from both sources for only 23 of the 33 commodities. The solid line represents 1:1 agreement, representing the theoretical point (in each case) where expert opinion and grower reports would have been in complete agreement; the dashed line is the best linear fit to the actual data $(y=0.96 x+38)$.

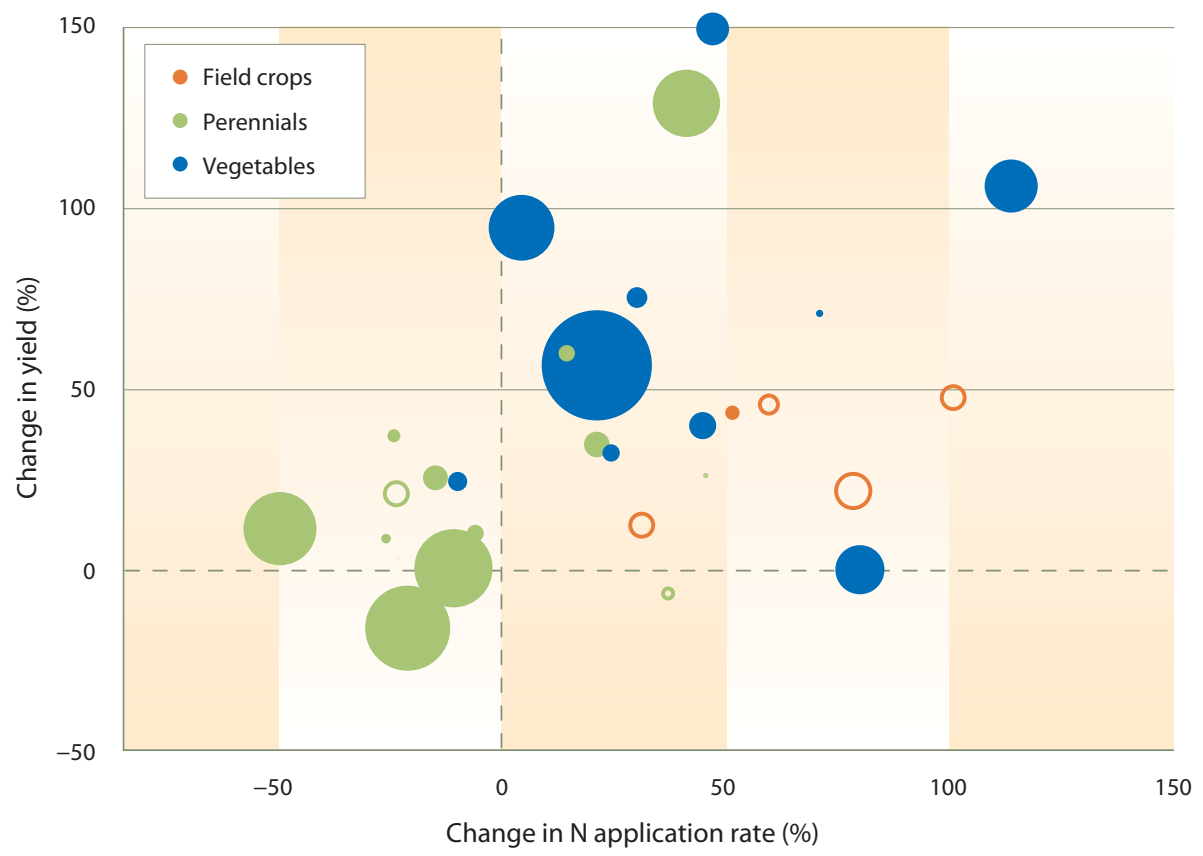

Fig. 4. Changes in nitrogen application rates, yields and cropped area. The size of circle represents the percentage change in the area cultivated for that particular crop between 1973 and 2005; closed circles represent increases in area and open circles represent declines in area. were selected to represent variations in California's agricultural regions (such as the Imperial Valley versus the Salinas Valley) as well as the breadth of management practices (such as furrow versus drip irrigation). Compiling studies that span the geographic and production continuum was important because of the potential differences in nitrogen application with the various environmental conditions and production techniques.

Not all of the available studies were included in the database. Some studies were omitted because studies of the same crop often recycle the descriptions and estimates of nitrogen use until management practices change significantly, and thus inclusion of every study would have skewed the estimate. An average of two studies were included for each crop, but the number of studies included ranged from one to five. Data were averaged to provide a representative value of nitrogen fertilizer use for each crop based on expert opinion.

Grower data. Estimates from grower reports included all nitrogen fertilizer application rates for the respective crops from the USDA Agricultural Chemical Use Program reports between 1999 and 2009 (USDA NASS 2010). We extended the starting date to 1999 to accommodate the USDA's variable schedule for these surveys. By adding 1999, we were able to obtain an additional year of data - in some cases doubling the available data - in particular for fruit and nut crops, such as almond, which are key crops in California. These data were averaged by crop to determine a typical nitrogen application rate reported by growers.

Discrepancy between expert and grower data. Our results show that experts believe growers apply more nitrogen - in fertilizer - than the amount that growers report applying (fig. 3). Both expert and grower data were available for 23 crops, and experts suggest that the average nitrogen fertilizer use per acre for all of these crops is 38 pounds higher than growers report. One possible explanation for this discrepancy is that the expert opinion reflects the application rates for a "well-managed" farm with good soil and favorable environmental conditions, and therefore high yield. However, producers with lower management intensity or more marginal land may apply less than experts expect. Another possible 
explanation is that the data reflect asymmetry in the scales of focus and methods of data collection. The USDA grower surveys are statewide, while the expert UC Cost and Return Studies have a regional focus. Thus, the latter may be sampling regions where the productivity and fertilizer demands are greater. The difference between expert and grower values for nitrogen fertilizer use highlights both the variation in the available information and the need to reconcile estimates more generally.

Because of the difference between expert and grower accounts and the uncertainty regarding the real relationship of the two, we calculated the simple average of the two values to determine the representative rate. Our representative rate approximates nitrogen use by crop for 2005 (table 1). The 33 crops were selected based on their current contribution to California's agricultural industry; each represents more than $1 \%$ of the annual value of agricultural products or the agricultural acreage, excluding animal products and alfalfa.

\section{Nitrogen use and crop trends}

While nitrogen fertilizer use on a crop-by-crop basis has risen over the last three decades, this increase has been more modest than fertilizer sales suggest. Between 1973 and 2005, fertilizer sales increased $31 \%$, but nitrogen application rates increased only $25 \%$ across the 33 crops (fig. 1, table 1). (While both sets of data were available for 23 crops, we used the data that were available - expert or grower - for the other 10.) Across crops, an average of 161 pounds of nitrogen was applied per acre in 2005 versus 130 pounds of nitrogen in 1973. Over the time period examined, application rates increased less than $10 \%$ for 13 of the 33 crops (39\%), and decreased for 11 of these crops (33\%). Since the amount of irrigated cropland remained relatively stable over this time period, the calculated average rate of increase is nearly 33\% less than the fertilizer sales data suggest.

\section{Shifting toward nitrogen-intensive} crops. What then accounts for the rise in nitrogen fertilizer sales between the 1973 survey and the present? While the average increase in nitrogen application rates was modest, the rates used on some commodities increased significantly. In addition, some of these commodities simultaneously increased in area (fig. 4). For example, the area of almonds and carrots increased by $174 \%$ and $124 \%$, respectively, while their respective nitrogen application rates increased $41 \%$ and $80 \%$ to 179 and 216 pounds of nitrogen per acre (table 1). We hypothesize that the increased nitrogen sales seem to be partly a consequence of the shift to commodities with higher nitrogen demands. Increased nitrogen fertilizer sales are not solely a result of an increase in application rate but are also due to an interaction between changes in application rates and

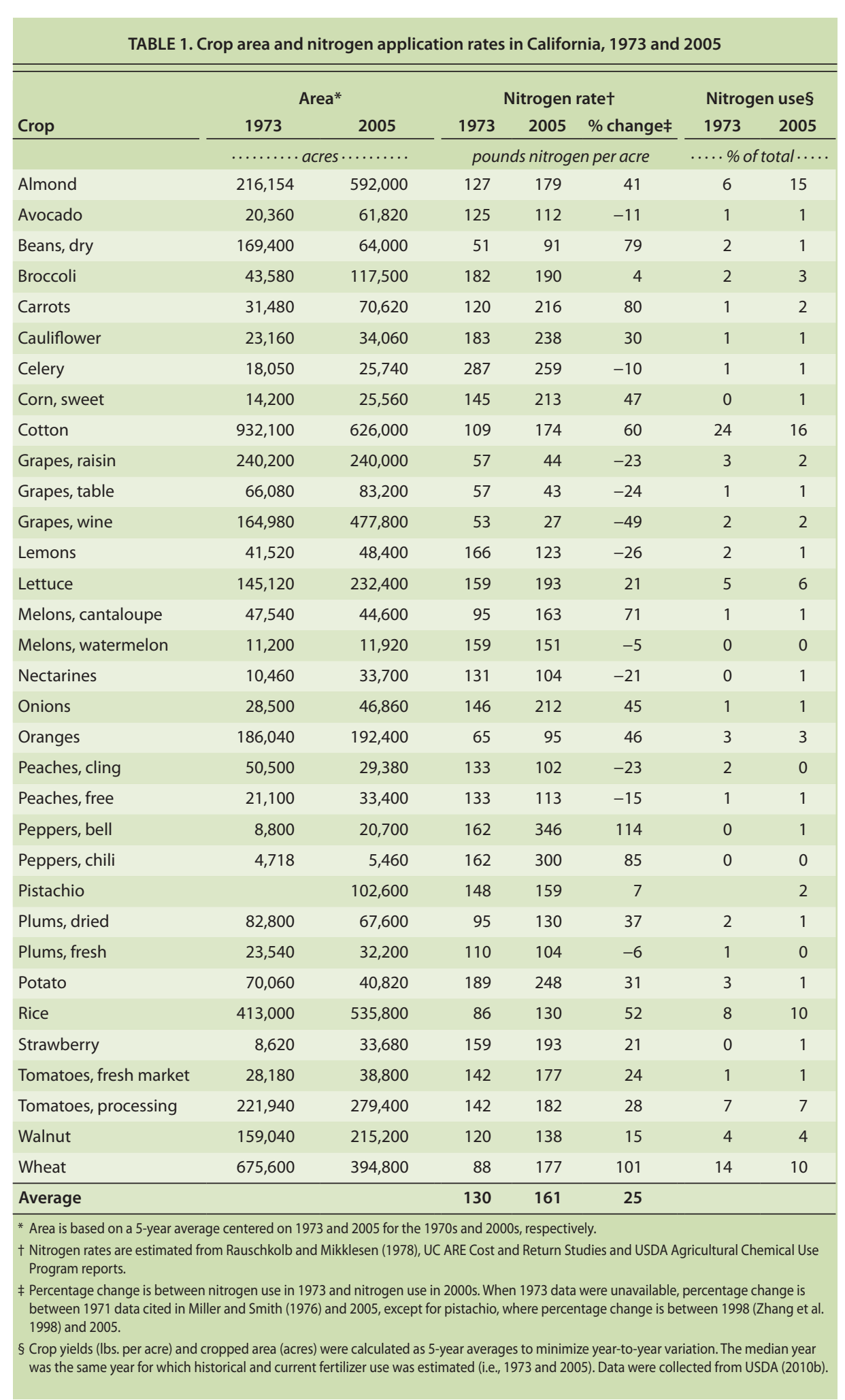


shifts toward a more nitrogen-intensive crop mix.

Using nitrogen more efficiently. Simply applying a greater amount of nitrogen fertilizer in and of itself is not necessarily harmful. It is the fraction of excess nitrogen applied that poses a threat to the environment. For almost every crop examined, yields and nitrogen uptake increase with greater nitrogen supply (fig. 4). These data clearly show the positive effect increased nitrogen use has had on California's ability to produce food. Because the rate of change of yields is often greater than that of nitrogen use, these findings further suggest that growers of the 33 commodities examined have, on average, become more agronomically

\begin{tabular}{|c|c|c|c|}
\hline \multirow[b]{2}{*}{ Crop } & \multicolumn{2}{|c|}{ Nitrogen guidelines } & \multirow[b]{2}{*}{ Source } \\
\hline & Minimum & Maximum & \\
\hline & \multicolumn{2}{|c|}{...... pounds per acre.....} & \\
\hline Alfalfa & 0 & 50 & Meyer et al. 2007. Pub. 3512 \\
\hline Almond & 100 & 200 & Weinbaum 1996. Pub. 3364 \\
\hline Avocado & 67 & 100 & $\begin{array}{l}\text { Faber 2005. CE Ventura Avocado Handbook and } \\
\text { Pub. } 3436\end{array}$ \\
\hline Bean, dry & 86 & 116 & Long et al. 2010. Pub. 8402 \\
\hline Broccoli & 100 & 200 & LeStrange et al. 2010. Pub. 7211 \\
\hline Carrot & 100 & 250 & Nunez et al. 2008. Pub. 7226 \\
\hline Celery & 200 & 275 & Daugovish et al. 2008. Pub. 7220 \\
\hline Corn & 150 & 275 & http://agri.ucdavis.edu \\
\hline Corn, sweet & 100 & 200 & Smith et al. 1997. Pub. 7223 \\
\hline Cotton & 100 & 200 & Hake et al. 1996. Pub. 3352 \\
\hline Grape, raisin & 20 & 60 & Christensen et al. 2000. Pub. 3393 \\
\hline Lawn (heavy soil) & 174 & 261 & Harivandi and Gibeault 1997. Pub. 7227 \\
\hline Lawn (shade) & 87 & 130 & Harivandi and Gibeault 1996. Pub. 7214 \\
\hline Lettuce & 170 & 220 & Jackson et al. 1996. Pubs. 7215 and 7216 \\
\hline Melon, cantaloupe & 80 & 150 & Hartz et al. 2008. Pub. 7218 \\
\hline Melon, watermelon & $\dagger$ & 160 & Baameur et al. 2009. Pub. 7213 \\
\hline Melons (mixed) & 100 & 150 & Mayberry et al. 1996. Pub. 7209 \\
\hline Nectarine & 100 & 150 & Pub. 3389 \\
\hline Oats & 50 & 120 & Munier et al. Pub. 8167 \\
\hline Onion & 100 & 400 & Voss et al. 1999. Pub. 7242 \\
\hline Peach, cling & 50 & 100 & Norton et al. 2007. Pub. 8276 \\
\hline Peach, free & 50 & 100 & Norton et al. 2009. Pub. 9358 \\
\hline Pepper, bell & 180 & 240 & Hartz et al. 2008. Pub. 7217 \\
\hline Pepper, chili & 150 & 200 & Smith et al. 1998. Pub. 7244 \\
\hline Pistachios & 100 & 225 & Beede et al. 2005. In Ferguson et al. 2009 \\
\hline Plums, dried (prunes) & $\dagger$ & 100 & Norton et al. 2007. Pub. 8264 \\
\hline Plums, fresh & 110 & 150 & Johnson and Uriu 1989. Pub. 3331 \\
\hline Rice & 110 & 145 & Mutters et al. 2009. Pub. 3514 \\
\hline Safflower & 100 & 150 & Kafka and Kearney 1998. Pub. 21565 \\
\hline Strawberry & 150 & 300 & Strand et al. 2008. Pub. 3351 \\
\hline Tomatoes, fresh market & 125 & 350 & Le Strange et al. 2000. Pub. 8017 \\
\hline Tomatoes, processing & 100 & 150 & Hartz et al. 2008. Pub. 7228 \\
\hline Walnuts & 150 & 200 & $\begin{array}{l}\text { Anderson et al. 2006. Pub. 21623. Weinbaum et al. } \\
\text { 1998. Pub. } 3373\end{array}$ \\
\hline Wheat & 100 & 240 & Munier et al. 2006. Pub. 8167 \\
\hline
\end{tabular}

nitrogen-efficient (in the technical, not the economic, sense) than in 1973. For most crops, less nitrogen is applied per unit of product.

\section{Judicious nitrogen use?}

UC researchers have historically established nitrogen rate guidelines through replicated research trials. These guidelines are not recommendations. Whereas recommendations prescribe nitrogen rates appropriate under specific production conditions, guidelines are ranges of nitrogen rates that are usually sufficient to obtain maximum production. Ranges are often large to account for the diversity of production conditions encountered. Guidelines are widely available in bulletins and reports published by UC Agriculture and Natural Resources (ANR). We assembled a database of the most recent nitrogen rate guidelines to evaluate (1) if they reflect current cropping conditions and (2) if the estimates of current nitrogen application rates fall within the published guidelines (table 2).

Nitrogen guidelines. We located periodic ANR publications with nitrogen guidelines that have been published within the last 25 years for 28 of the 33 crops. Guidelines for 16, 18 and 24 of the 28 crops were published within the last 5, 10 and 15 years, respectively. In most cases, more recent publications were revisions of previously published guidelines to incorporate findings from new research, changes in management practices, and crop genetics. We were unable to find recent print publications listing nitrogen application guidelines specific to California for five crops (potato, wine grapes, table grapes, lemons and oranges). Information to guide nitrogen fertilizer use for these crops was available, however, either online (Peacock et al. 1998) or in other forms used to support nitrogen management in some systems (that is, critical values for tissue tests) (Flint 1991; Ingels 1994) or more generally for the western United States (Strand 2006).

Beyond these 33 crops though, information on appropriate nitrogen fertilizer management is less readily available.

Yet, we conclude that ANR nitrogen rate guidelines are generally up to date with the needs of current cropping conditions for two reasons: (1) the 33 crops studied are grown on more than $70 \%$ of the nonalfalfa California cropland (alfalfa does 
not need nitrogen fertilizer because it fixes its own nitrogen) and (2) most guidelines were published within a reasonably recent period. This is not to suggest that there is no longer a need to perform nitrogen rate trials. Replicated research trials to refine current practices and to account for any future changes in various management practices are still required.

Nitrogen use. Do growers apply nitrogen in accordance with research results? We compared our 2005 estimates, which can be said to represent typical applications by growers for a particular crop, to the published UC nitrogen rate guidelines (table 3). We found that the maximum values of the guideline ranges were nearly double the minimum values, a range that should be sufficient to account for heterogeneous cropping conditions. Our representative application rates were within the guidelines for 17 crops (61\%), indicating that nitrogen is generally applied in line with research guidelines and, in that sense, can be considered "best management" practice. For nine of the crops (32\%), typical application rates exceeded the maximum value in the guidelines. Vegetables and annual fruits accounted for the largest percentage of crops that fell within that category, with $42 \%$ of the crops receiving more nitrogen than suggested by guidelines. Whereas the majority of crops appear to be fertilized appropriately, the latter results suggest that in nearly one-third of California cropping systems, either the research underestimates nitrogen requirements for on-farm cropping conditions or the producers, on average, overapply nitrogen fertilizer.

\section{Nitrogen management}

The need to balance the benefits of nitrogen fertilizer use (such as increased food supply) with the costs (such as water and air pollution) is clear. However, uncertainty about basic questions on nitrogen use obstructs substantive discourse and cooperation among stakeholders toward workable solutions. While still not devoid of uncertainty, the typical nitrogen application rates established in this research can be used to identify priorities for nitrogen research, outreach and policy.

High-nitrogen-use crops. Fertilizer use is not distributed equally among crops. Of the 345,900 tons of nitrogen fertilizer accounted for in the application rates of the
TABLE 3. Relevance of current nitrogen rate guidelines

\begin{tabular}{|c|c|c|c|c|c|}
\hline Crop type & $\mathbf{N}$ & Range of guideline* & Withint & Over‡ & Average excess§ \\
\hline & & $\%$, average $\pm S D$ & $\cdots \cdots \cdots$ & $\cdots \cdots$ & Ibs. nitrogen per acre $\pm S D$ \\
\hline Field crops & 4 & $73 \pm 46$ & 100 & - & - \\
\hline Perennials & 12 & $88 \pm 54$ & 50 & 33 & $14 \pm 12$ \\
\hline $\begin{array}{l}\text { Vegetables and } \\
\text { annual fruits }\end{array}$ & 12 & $101 \pm 83$ & 58 & 42 & $53 \pm 47$ \\
\hline All crops & 28 & $90 \pm 65$ & 57 & 36 & $36 \pm 39$ \\
\hline \multicolumn{6}{|c|}{$\begin{array}{l}\text { * Calculated as the percentage difference between the maximum and minimum rate in the guideline. Average and standard deviation are } \\
\text { among the crops in the crop type. } \\
\text { † The percentage of crops with an average nitrogen application rate that falls within the range outlined by the UC guideline. } \\
\text { ₹ The percentage of crops with an average nitrogen application rate exceeding the maximum listed in the UC guideline. } \\
\text { § Excess refers to the amount of nitrogen applied above the maximum rate in the guideline. }\end{array}$} \\
\hline
\end{tabular}

33 commodities considered in this study, approximately $34 \%$ is applied to perennials, $27 \%$ to vegetables and $42 \%$ to field crops. Notably, our estimates show that relatively few crops account for much of the nitrogen use. Multiplying the averagenitrogen-use estimates for each crop by the average harvested acreage for 2002 to 2007 indicates cotton received the largest fraction of the total nitrogen applied, $16 \%$, while almond received $15 \%$, rice and wheat each received $10 \%$, processing tomatoes received $7 \%$ and lettuce received $6 \%$. Altogether these six crops account for $64 \%$ of the total nitrogen use (fig. 5). Moreover, these estimates may be conservative for the perennials and field crops in this small group because only bearing and harvested areas, respectively, were used in these calculations. Even with the uncertainty surrounding the precision of our estimates and with the relative changes in cropped area that occur year to year, it is difficult to imagine a scenario

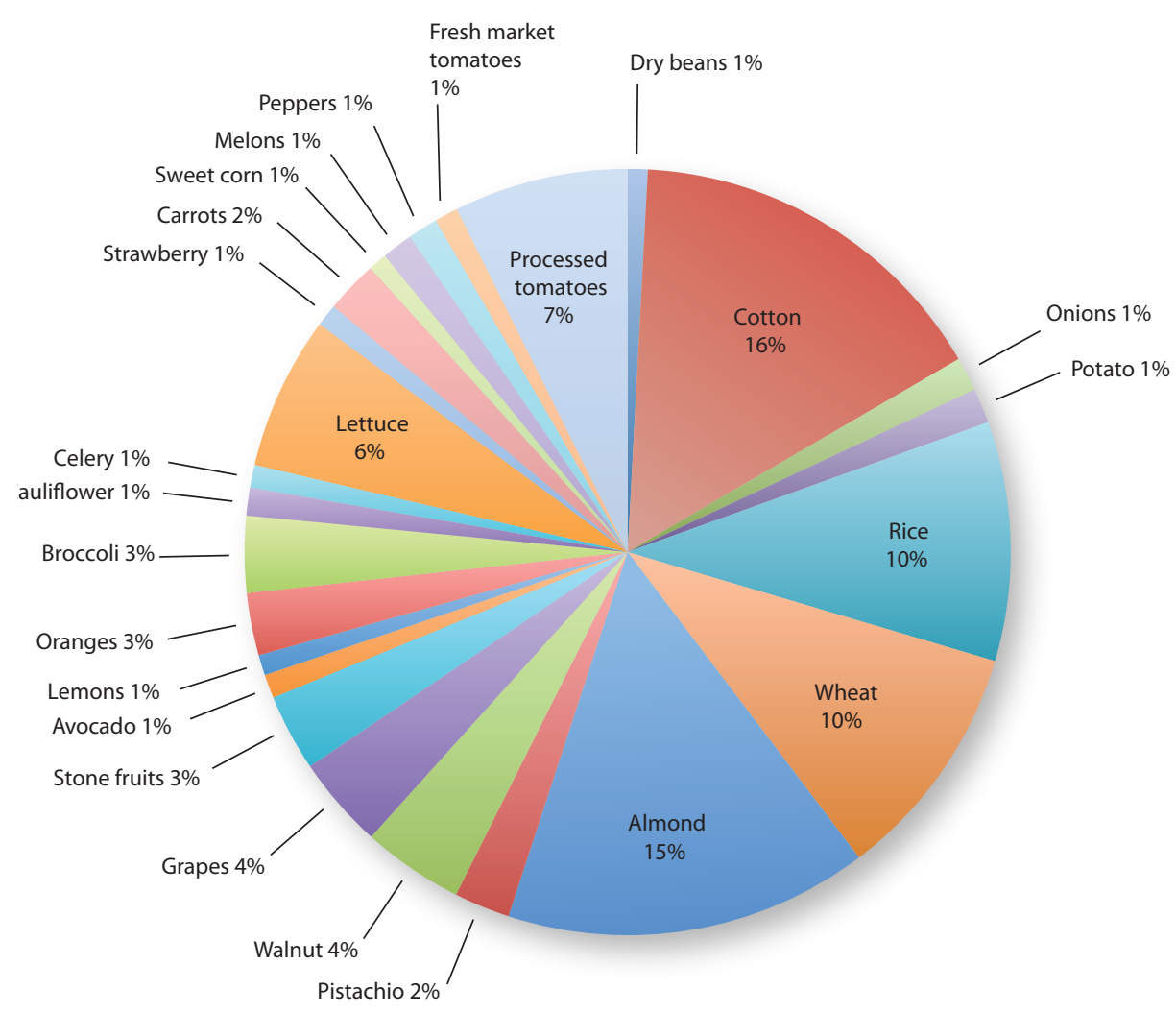

Fig. 5. Relative proportion of nitrogen fertilizer use of the 33 commodities included in the analysis. Stone fruits include peaches, nectarines and dried and fresh plums. Grapes include wine, table and raisin grapes. 
where other crops could account for as much total inorganic nitrogen fertilizer use in the state, at least in the short term.

Thus, the highest priority becomes understanding nitrogen management (and the fate of applied nitrogen) in these cropping systems, which include a representative range of crop types and are commonly grown with an array of soil, irrigation and fertility management practices. Indeed, nitrogen research activities have focused attention on these crops as of late. Evidence of that are the ongoing experiments to quantify nitrous oxide emissions in cotton, almond, lettuce, wheat and tomatoes, as well as using the Salinas Valley, the epicenter of lettuce production, as one of the two pilot areas in the report on nitrate to the California Legislature.

Excess nitrogen. What these data do not allow for is predicting the fraction of nitrogen fertilizer that is applied in excess of crop uptake. There are clearly some crops not identified by this analysis that may receive excess nitrogen application per unit of area. Given the significance of surplus nitrogen applications to environmental pollution, it is probable that even though such crops may account for relatively small cultivated areas, they may still become hot

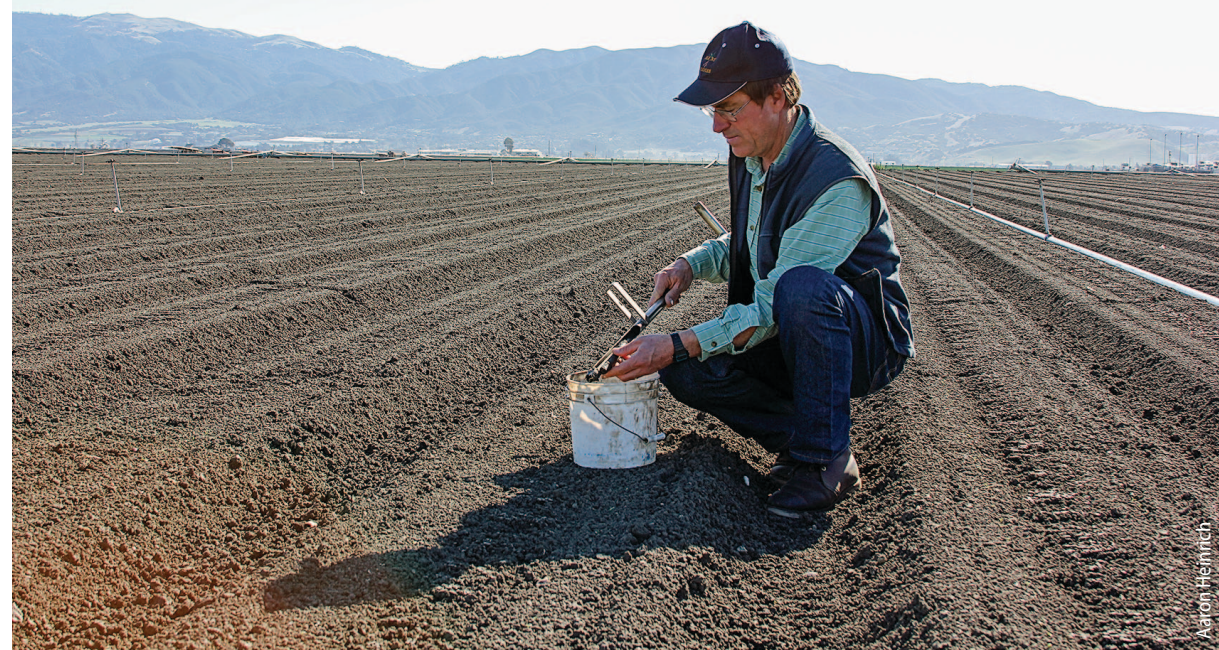

Richard Smith, UC Cooperative Extension farm advisor in Monterey County, tests for nitrogen. Salinas Valley is one of two pilot areas studied in a report on nitrate to the California Legislature.

spots of potential nitrogen emissions. In addition to considering total nitrogen use, which will be weighted by crop area and application rate, it is important to calculate surplus nitrogen when setting priorities. Calculating this surplus, however, requires data on yield, nitrogen and moisture content of harvested products, and nitrogen application, much of which is not available in a comprehensive way. Better information on these four parameters would go far toward increasing our knowledge of the nitrogen pollution hot

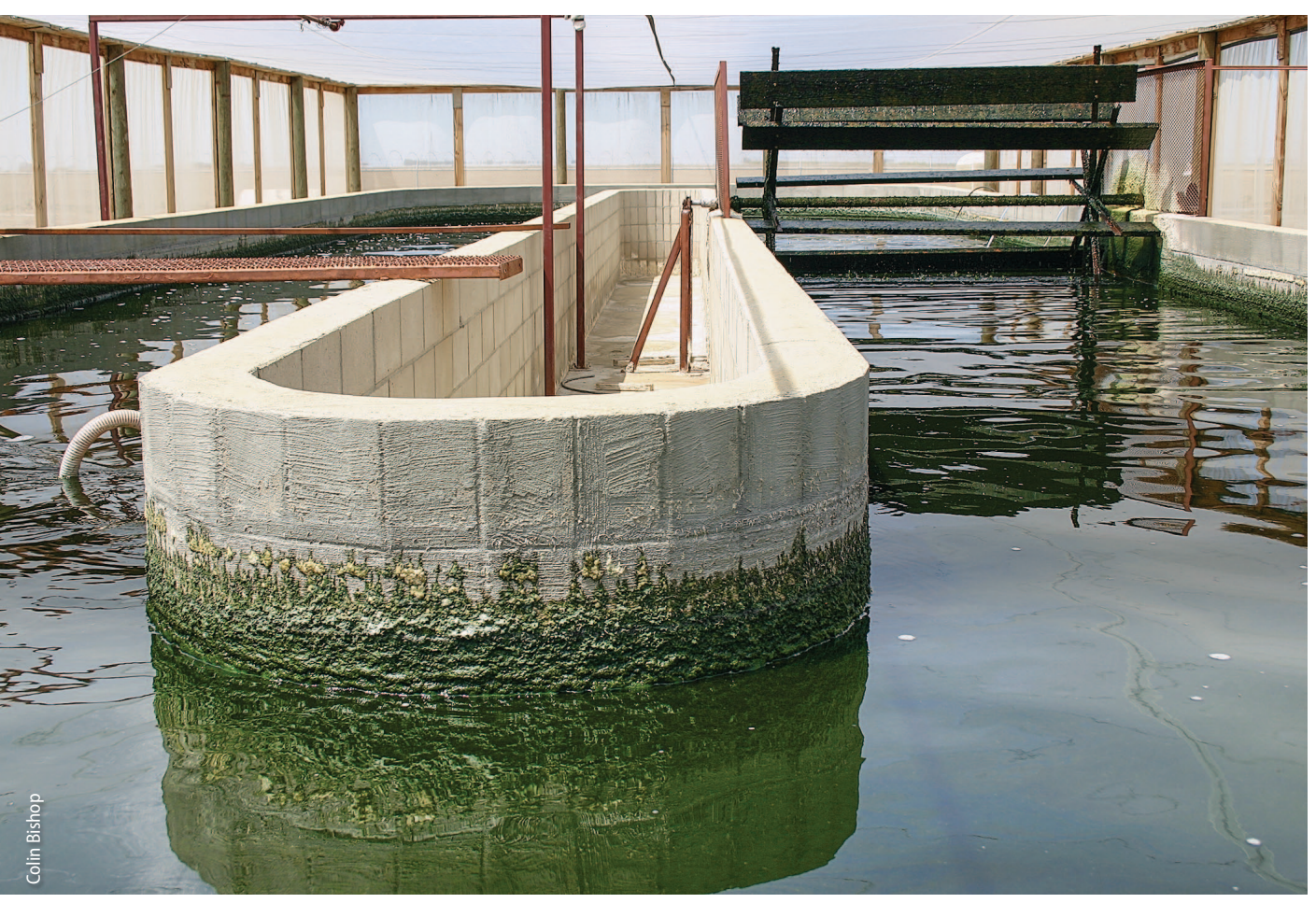

Water treatment facilities at San Joaquin Valley farms. Irrigation water high in nitrogen can contribute to growth of algal blooms, especially blue-green algae. spots, as well as of leverage points to balance economic and food production benefits of nitrogen fertilizer use with threats to California's human and natural capital.

\section{A way forward}

Agricultural nitrogen fertilizer use sits at the nexus of multiple social and environmental debates in California. Policymakers appear ready to act, but finding solutions workable to the diverse constituencies is severely constrained by a lack of credible, comprehensive information. The ability to target any remedial action - incentives, regulations, education, research, and so on - requires better information on the location and severity of the concern. As shown, available data lack reliability and coverage, presenting significant barriers to scientifically sound efforts to address this issue, which therefore suggests the need for a new approach.

One option would be the development of a grower self-reporting system for total nitrogen applications to serve as a warning sign of excess nitrogen use. Pesticideuse reporting provides a positive example that can inform design of nutrient reporting. Information derived from the pesticide-use reporting system serves as the foundation for better information, science and management (see Zhang, unpublished, an online bibliography of research and trade publications that rely heavily on the pesticide-use database to understand the extent of agricultural, environmental and human health effects of pesticide use). Establishing a reporting system would require careful consideration of its fundamentals, however. Concerns over 
costs and institutional barriers will likely be among the most cited reasons for resistance to the idea and may challenge the efficacy of the system.

California, however, is at an opportune juncture for developing such a reporting system, which could help farmers save on fertilizer costs while, at the same time, reinforcing the good practice of many producers and reducing agriculture's impact on the environment. So, we recommend establishing a multistakeholder process to ensure a workable and useful solution for growers, regulators and scientists alike. Funding to develop a practical, costeffective fertilizer application reporting system would seem to be compatible with the mandate of the California Department of Agriculture's Fertilizer Research and Education Program.

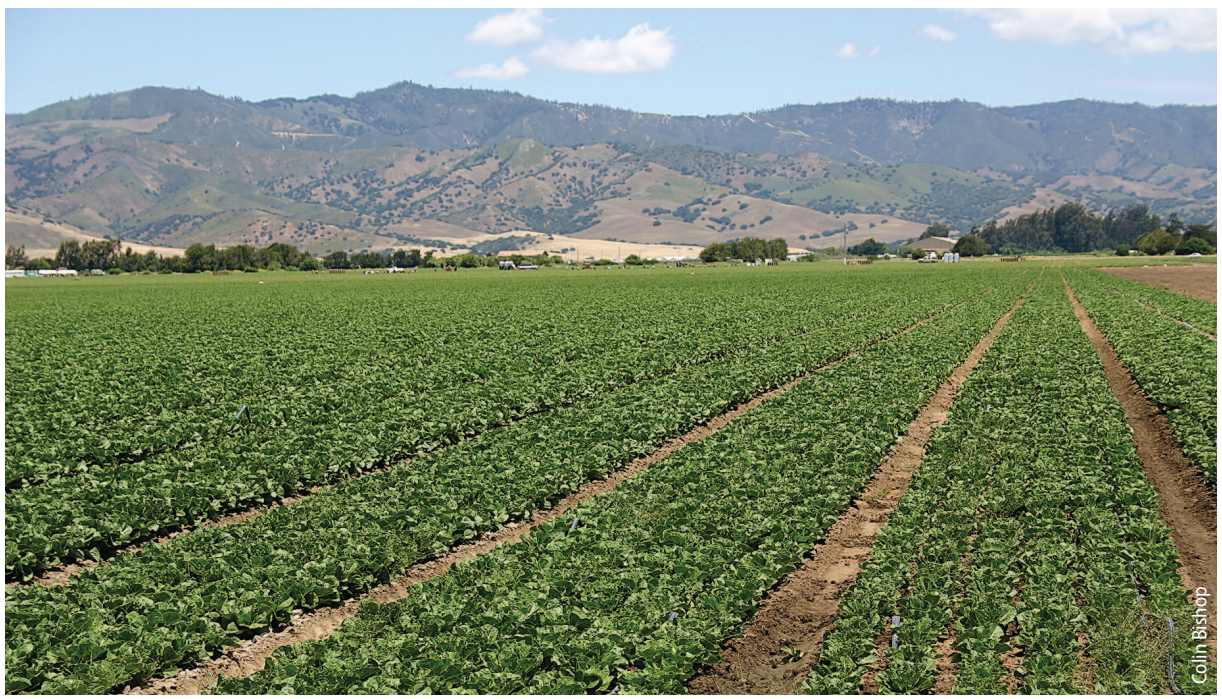

Lettuce, a major Salinas Valley crop, uses significant nitrogen fertilizer. However, the quantity used cannot predict the fraction applied in excess of crop uptake, or where nitrogen hot spots may arise.

When facing an issue of such fundamental importance to our state - involving trade-offs between the basic needs of food production versus clean water and air - it seems reasonable to invest effort to develop data necessary to make fully informed decisions. Decisions based on currently available data, which are unreliable and inadequate, risk unintended negative consequences and reduce chances that objectives will be balanced in an efficient and effective way.

T.S. Rosenstock and D. Liptzin were Postdoctoral Fellows, Agricultural Sustainability Institute, UC Davis, and are now, respectively, Environmental Impacts Scientist, World Agroforestry Centre and Research Fellow, University of New Hampshire; J. Six was Professor of Agroecology, Department of Plant Sciences, UC Davis, and is now Professor of Sustainable Agroecosystems, ETH-Zurich; and T.P. Tomich is Director, Agricultural Sustainability Institute, UC Davis.

The authors thank C. Snyder, C. Garnache, S. Ogburn, C. Bishop, T. Harter, J. Dickey, five anonymous reviewers and the editors for their comments on earlier versions of the manuscript. The David and Lucile Packard Foundation supported this research as part of the California Nitrogen Assessment.

\section{References}

Ash N, Blanco H, Brown C, et al. 2010. Ecosystems and Human Well-Being: A Manual for Assessment Practitioners. Washington, DC: Island Press. p 264.

Broadbent FE, Rauschkolb RS. 1977. Nitrogen fertilization and water pollution. Calif Agri 31 (5):24-25.

Davidson EA, David MB, Galloway JN, et al. 2012. Excess nitrogen in the U.S. environment: Trends, risks, and solutions. Iss Ecology 15:17.

Dillon J, Edinger-Marshall S, Letey J. 1999. Farmers adopt new irrigation and fertilizer techniques: Changes could help growers maintain yields, protect water quality. Calif Agri 53(1): 24-31.

Flint ML. 1991. Integrated Pest Management for Citrus. UC ANR Pub. Oakland, CA.

Galloway JN, Aber JD, JW Erisman, et al. 2003. The nitrogen cascade. BioScience 53(4):341-56.

Gardner JB, Drinkwater LE. 2009. The fate of nitrogen in grain cropping systems: A meta-analysis of $15 \mathrm{~N}$ field experiments. Ecol Appl 19:2167-84.

Harding R, Embleton TW, Jones WW, et al. 1963. Leaching and gaseous losses of nitrogen from some nontilled California soils. Agron J 55(6):515-8.

Hartley C, van Kessel CV. 2003. Results of the 2003 UC Davis Rice Fertility Management Survey. UC Rice Research Information Program website, www.ucdavis.edu/ uccerice/NEWS/FertilityMgtSurvey2003.pdf.

Hoben JP, Gehl R, Millar N, et al. 2011. Nonlinear nitrous oxide (N2O) response to nitrogen fertilizer in on-farm corn crops of the US Midwest. Glob Change Biol 17:1140-52.

Ingels C. 1994. Protecting Groundwater Quality in Citrus Production. UC ANR Pub. Oakland, CA.
Integrated Nitrogen Committee, 2011. Reactive Nitrogen in the United States: An Analysis of Inputs, Flows, Consequences, and Management Options. A Report of the EPA Science Advisory Board. Washington, D.C.

IPCC, 2007. Climate Change 2007: The Physical Science Basis. Contribution of Working Group I to the Fourth Assessment Report of the Intergovernmental Panel on Climate Change. Cambridge University Press. Cambridge, United Kingdom and New York, NY

Ladha JK, Reddy CK, Padre A, et al. 2011. Role of nitrogen fertilization in sustaining organic matter in cultivated soils. J Environ Qual 40:1-11.

Linquist B, van Groenigen KJ, Adviento-Borbe MA, et al. 2012. An agronomic assessment of greenhouse gas emissions from major cereal crops. Glob Change Biol 18:194-209

Lopus SE, Santibáñez MP, Beede RH, et al. 2010. Survey examines the adoption of perceived best management practices for almond nutrition. Calif Agri 64(3):149-54.

Millennium Ecosystem Assessment. 2005. Ecosystems and Human Well-Being: Synthesis. Washington, DC: Island Press.

Miller RJ, Smith RB. 1976. Nitrogen balance in the southern San Joaquin Valley. J Environ Qual 5:274-8.

Peacock WL, Christensen LP, Hirschfelt DJ. 1998. Best Management Practices for Nitrogen Fertilization of Grapevines. Tulare County UCCE, Pub NG4-96.

Proebsting EL. 1948. Nitrogen fertilizer usually beneficial to soils of California. Calif Agri 2(1):10.

Rauschkolb RS, Mikkelsen DS. 1978. Survey of Fertilizer Use in California - 1973. UC Division of Agricultural Sciences Bulletin 1887. p 25.
Strand L. 2006. Integrated Pest Management for Potatoes in the Western United States (2nd ed.). UC ANR Pub 3316. Oakland, CA.

Townsend AR, Howarth RW, Bazzaz FA, et al. 2003. Human health effects of a changing global nitrogen cycle. Front Ecol Environ 1(5):240-6.

[UCD] UC Davis Agricultural and Resource Economics. 2010. Cost and Return Studies. http://coststudies.ucdavis. edu/ (accessed Jan. 5, 2010; verified Feb. 1, 2011).

USDA NASS. 2010a. National Agricultural Statistics Service Surveys: Agricultural Chemical Use Program. www. nass.usda.gov/Surveys/Guide_to_NASS_Surveys/Chemical_Use/index.asp (accessed Jan. 5, 2010; verified Feb. 1, 2011).

USDA. 2010b. National Agricultural Statistics Services Quick Stats.www.nass.usda.gov/Data_and_Statistics/ Quick_Stats/index.asp (accessed 10 November 2009; verified 1 Feb. 2011).

Van Groenigen JW, Velthof GL, Oenema O, et al. 2010. Towards an agronomic assessment of $\mathrm{N} 2 \mathrm{O}$ emissions: A case study for arable crops. Eur J Soil Sci 61:903-13.

Zhang M, Geng S, Smallwood KS. 2009. Assessing groundwater nitrate contamination for resource and landscape management. Ambio 27(3):170-4.

Zhang M. Unpublished. Bibliography of Studies Citing the PUR Database. http://agis.ucdavis.edu/pur/pdf/2011/ PUR-citations.pdf/ (accessed July 26, 2012; verified July 30, 2012). 